\title{
SOSIALISASI PROTOKOL KESEHATAN DI MASA PANDEMI MELALUI AKTIFITAS MEWARNAI DAMAR KURUNG PADA ANAK USIA DINI
}

\author{
Riyadlotus Sholichah \\ STAI Daruttaqwa Gresik \\ riyadlotussholichah@staida.gresik.ac.id \\ Nur Rachmadani Fadhilah \\ STAI Daruttaqwa Gresik \\ nurrachmadani06@gmail.com
}

\begin{abstract}
During a pandemic, the socialization of health protocols to children is important and needs to be researched. Child health protocol education needs serious attention. Not all the socialization of health protocols to children is able to present and frame health protocol material through an activity that is interesting, fun and in accordance with the characteristics of the child. An activity that is close to the child's daily life is play.

This paper aims to describe the results of research on the importance of socializing early childhood health protocols through coloring Damar brackets. Damar brackets are a local cultural product of Gresik, East Java in the form of cube lanterns. The four sides are made of paper decorated with pictures / paintings, telling a familiar, cheerful and interesting daily life. In this study, the painting on the side of the resin brackets was substituted with the Health protocol image. The method in this research is descriptive qualitative. So this article describes how to socialize the Health protocol in early childhood through Damar Kurung coloring activities.

Keywords: socialization of health protocols, pandemics, resin brackets, early childhood
\end{abstract}

\begin{abstract}
Abstrak: Di masa pandemi, sosialisasi protokol kesehatan pada anak menjadi hal penting dan perlu diteliti. Edukasi protokol kesehatan anak, perlu menjadi perhatian serius. Tidak semua sosialisasi protokol Kesehatan pada anak mampu menghadirkan dan membingkai materi protokol kesehatan melalui sebuah aktifitas yang menarik, menyenangkan dan sesuai dengan karakteristik anak Aktifitas yang dekat dengan keseharian anak adalah kegiatan bermain.

Tulisan ini bertujuan mendeskripsikan hasil penelitian tentang pentingnya sosialisasi protokol kesehatan anak usia dini melalui aktifitas mewarnai Damar kurung. Damar kurung adalah produk budaya lokal Gresik Jawa Timur berbentuk lampion kubus. Empat sisinya terbuat dari kertas yang dihiasi gambar/lukisan, menceritakan kehidupan sehari-hari yang familiar, ceria dan menarik. Dalam penelitian ini, lukisan disisi damar kurung disubtitusi dengan gambar protokol Kesehatan. Metode dalam penelitian ini adalah kualitatif deskriptif. Jadi dalam artikel ini mendeskripsikan bagaimana upaya sosialisasi protocol Kesehatan pada anak usia dini melalui aktifitas mewarna Damar Kurung.

Kata Kunci: sosialisasi protocol kesehatan, pandemic, damar kurung, anak usia dini
\end{abstract}

\section{Pendahuluan}

Gresik merupakan salah satu kabupaten di Provinsi Jawa Timur. Selain mendapatkan julukan sebagai kota santri dan kota industri, Gresik juga mempunyai peninggalan seni budaya, yaitu damar kurung. Damar kurung merupakan budaya seni lukisan yang ditorehkan pada lampion atau lentera. Lukisan yang ada pada damar kurung menggambarkan tentang manusia dan berbagai aktivitas kegiatan kehidupan sehari-hari masyarakat Gresik yakni kesibukan 
berdagang, beribadah dan bekerja di pesisir dan juga di tengah laut, aktifitas yang banyak digeluti masyrakat Gresik pada masa lalu. Karena itulah Damar Kurung dijadikan ikon dari kota Gresik. Damar kurung mulai dikenal oleh masyarakat Indonesia setelah diperkenalkan dan dipopulerkan oleh Mbah Masmundari. Sebenarnya damar kurung sudah ada sejak zaman Hindu-Budha ${ }^{1}$. Namun sayang, dulu banyak yang tidak mengetahui damar kurung. Keberadaan damar kurung kurang berkembang dan hampir punah. Banyak generasi muda yang kurang mnegenal kekayaan dan kearifan local budaya daerahnya sendiri. Segala upaya pelestarian lukisan lentera damar kurung masih tetap dilakukan. Salah satunya adalah dengan mengadakan lomba lukis, lomba menggambar atau mengikuti pameran-pameran yang khusus menampilkan karya seni damar kurung.

Damar kurung merupakan sebuah warisan kebudayaan yang merupakan hasil dari akulturasi masyarakat Jawa dan bangsa Cina pada abad ke-11. Damar kurung terinspirasi dari lampion yang berasal dari kebudayaan bangsa Cina yang dibawa dan telah menetap di pulau Jawa khususnya daerah Gresik. Lampion dari Cina ini memiliki bentuk bulat atau lonjong, dilapisi kertas berwarna merah atau putih yang memiliki filosofi tertentu. Lampion ini dihiasi dengan kaligrafi Cina. Lama-kelamaan kebudayaan Cina berupa lampion dengan kebudayaan Jawa saling mempengaruhi satu sama lain atau disebut akulturasi sehingga akhirnya menghasilkan kebudayaan baru yang disebut damar kurung. Damar Kurung merupakan sebuah lentera yang berbentuk persegi seperti sangkar burung namun kegunaannya hanya untuk hiasan, terbuat dari bambu dan dibalut dengan kertas berwarna putih dengan dihiasi motif yang menggambarkan kegiatan sehariharimasyarakat seperti kegiatan di pasar, mesjid, pantai dan menggambarkan objek seperti ombak dan pohon.Warna-warna yang digunakan adalah warna cerah seperti merah, kuning, hijau, dan biru. Di dalam damar kurung tersebut disediakan tempat untuk lilin atau lampu berwarna kuning.

Salah satu bentuk kegiatan yang dilaksanakan sebagai upaya pelestarian budaya Damar kurung bagi anak usia dini yaitu dengan aktifitas mewarnai Damar Kurung untuk sosialisasi pemahaman anak tentang Protokol kesehatan dengan melalui media damar kurung. Anak-anak menjadi salah satu kalangan yang rentan terpapar Covid-19. Oleh karenanya, orang tua perlu memberikan edukasi terkait pandemi Covid-19, agar anak mau menerapkan protokol kesehatan sehingga aman dari virus corona. Seperti diketahui, pandemi Covid-19 tak cuma berdampak bagi orang dewasa. Anak-anak pun ikut terkena imbasnya. Aktivitas mereka dibatasi yakni tak bisa bermain dengan teman sebaya. Terlebih, semua kegiatan sebagian besar melalui daring dan tidak tatap muka.

Pada tanggal 31 Desember 2019, World Health Organization (WHO) mendapatkan informasi mengenai kasus pneumonia yang terjadi di kota Wuhan, Provinsi Hubei, Cina. Tanggal 7 Januari 2020, otoritas Cina mengkonfirmasi telah mengidentifikasi virus baru, yaitu virus Corona, yang merupakan famili virus flu, seperti virus SARS dan MERS, yang mana dilaporkan lebih dari 2.000 kasus infeksi virus tersebut terjadi di Cina, termasuk di luar Provinsi Hubei. Virus Corona (CoV) merupakan famili virus yang menyebabkan penyakit mulai dari flu biasa hingga penyakit yang lebih berat seperti Middle East Respiratory Syndrome (MERS- SoV) dan Severe Acute Respiratory Syndrome (SARS-CoV). Pada 11 Februari 2020, WHO mengumumkan

\footnotetext{
${ }^{1}$ Rizky Sandika Wahyu, "Damar Kurung (Makna Lukisan Damar Kurung Sebagai Kesenian Masyarakat Gresik)” 2, no. 1 (2013): 114-23.
}

2 Riyadlotus Sholichah - Pengasuhan Berbasis Neurosain dan Kecerdasan Emosi dalam Pengasuhan Anak Usia Dini 
nama virus Corona jenis baru tersebut adalah Corona VirusDisease2019 (disingkat menjadi COVID-19) $)^{2}$.

\section{Pemahaman Protokol Kesehatan pada Anak Usia Dini}

Pandemi COVID-19 telah merubah tatanan dunia, memberikan dampak dan perubahan luar biasa bagi semua orang di segala bidang. Fenomena ini juga berdampak pada pola kehidupan anak usia dini di seluruh dunia. Termasuk anak-anak di Indonesia ${ }^{3}$. Dari data yang dirilis oleh Ikatan Dokter anak Indonesia (IDAI),WHO dan gugus tugas penanganan percepetan corona virus 19 yang dirilis bulan September 2020 menyebutkan bahwa 40 anak lebih telah meninggal dunia disinyalir karena ganasnya virus Corona ${ }^{4}$. Tingginya kasus covid anak di Indonesia dibandingkan di negara lain, mengindikasikan rendahnya praktik penerapan protokol kesehatan anak. Juga rendahnya, pengawasan orangtua, dalam intervensi mengontrol kedisiplinan anak menerapkan protokol kesehatan.

Masa inkubasi dapat bervariasi antar pasien, yaitu 2-14 hari setelah terpapar virus berdasarkan periode inkubasi yang ditunjukkan sebelumnya pada virus MERS. Masa inkubasi 24 hari telah diamati dalam penelitian terbaru. WHO mengatakan periode inkubasi yang panjang dapat mencerminkan paparan ganda Coronavirus. Penularan dari orang ke orang diperkirakan terjadi melalui droplet ketika orang yang terinfeksi batuk atau bersin, mirip dengan bagaimana influenza dan patogen pernapasan lainnya yang dapat terhirup ke dalam paru- paru. Penularan Covid-19 dapat juga terjadi dengan menyentuh permukaan atau objek yang memiliki virus di atasnya dan kemudian orang tersebut menyentuh mulut, hidung, atau mungkin mata mereka sendiri.

Menurut Pedoman Umum Perlindungan Anak Penanganan Covid-19, setiap anak tanpa kecuali berhak mendapatkan hak, perlindungan dan Informasi yang jelas tentang pencegahan Covid-19. Perilaku pola hidup sehat di masa pandemi ini tentunya sangat perlu diajarkan kepada anak sehingga mereka memahami benar pola hidup bersih dan sehat ${ }^{5}$. Selain itu, protokol kesehatan pencegahan Covid-19 ini juga perlu diajarkan kepada anak sehingga mereka tidak salah paham mengenai Covid-19 mengingat banyaknya informasi yang diterima mereka dari media sosial. Namun tidak semua anak dapat mengakses media sosisal. Keterbatasan ini bisa disebabkan karena minimnya akses internet untuk daerah dan wilayah teretentu, atau masih belum terjangkaunya fasilitas gawai bagi anak usia dini dari kalangan tertentu. Oleh karena itu, diperlukan media lain sebagai cara untuk sosialisasi pemahaman anak mengenai COVID-19 dan cara mencegahnya, sehingga anak akan semakin sadar dan menerapkan protokol kesehatan untuk pencegahan COVID19 dalam kehidupan sehari-hari.

Salah satu cara yang dapat digunakan untuk sosialisasi meningkatkan pemahaman anak tentang pencegahan COVID-19 adalah dengan menggunakan media yang menarik ${ }^{6}$. Salah satu

\footnotetext{
2 IDAI, "Panduan Klinis Tata Laksana COVID-19 Pada Anak,” Indonesian Pediatric Society, 2020, 33.

3 Wahyu Aji Fatma Dewi, "Dampak COVID-19 Terhadap Implementasi Pembelajaran Daring Di Sekolah Dasar," Edukatif: Jurnal Ilmu Pendidikan 2, no. 1 (2020): 55-61, https://doi.org/10.31004/edukatif.v2i1.89.

${ }^{4}$ IDAI, "Panduan Klinis Tata Laksana COVID-19 Pada Anak."

${ }^{5}$ KPPA, "Pedoman Umum Perlindungan Anak Penanganan COVID-19," 2020.

${ }^{6}$ Isfauzi Hadi Nugroho and Dema Yulianto, "Penerapan Disiplin Protokol Kesehatan Di Era KENORMALAN BARU PADA DUNIA PAUD,” Jurnal Al-Hikmah 8, no. 1 (2020): 150-56.
} 
kegiatan yang menarik bagi anak-anak adalah melalui kegiatan menggambar, mewarnai damar kurung.

\section{Hakikat Anak Usia Dini}

Anak usia dini memiliki rentang antara usia 0 sampai 8 tahun dan sedang mengalami sebuah proses tumbuh kembang yang unik. Sementara menurut WHO memaparkan bahwa anak adalah seseorang dengan rentang usia 0-18 tahun atau seseorang yang belum mencapai usia 18 tahun $^{7}$. Termasuk juga anak yang masih dalam kandungan (UU no 23 tahun 2002). Aspek tumbuh kembangnya meliputi bidang agama dan moral, fisik-motorik, kognitif, sosialemosional, bahasa dan seni. Proses tumbuh kembang ini akan dijalani dalam setiap tahapan oleh anak. Di masa ini juga masa peka terhadap aspek disiplin dan pengendalian diri anak. Secara kognitif anak usia dini diusia ini sudah mampu mengembangkan sikap disiplin melalui fungsi kognitif nya yang mulai tumbuh berkembang ${ }^{8}$. Sistem pengendalian diri anak dapat dibentuk melalui sebuah stimulasi yang diharapkan memunculkan sebuah sikap dan perilaku kepatuhan yang sesuai dengan tatanan nilai, norma dan ketentuan ketentuan yang berlaku sesuai dengan kondisi yang berkembang.

Stimulasi yang paling tepat yang dapat diaplikasikan pada anak usia Dini dalam memeberikan informasi ataupun mengubah perilaku anak adalah dengan media bermain. Bermain merupakan satu-satunya aktifitas yang sesuai dengan karakteristik anak usia dini. Aktifitas bermain ini bisa dikolaborasikan dengankegiatan bermanfaat lainnya yang bersifat mendidik'. Misalkan bermain warna, bermain angka, bermain gambar atau bermain sambal bercerita. Aktifitas mewarnai juga merupakan kegiatan bermain yang memberikan banyak efek positif bagi anak usia Dini. Aktifitas ini akan mendukung pada berkembangnya bebrapa aspek perkembangan pada anak usia dini ${ }^{10}$.

Beberapa aspek Perkembangan anak usia Dini yang menjadi focus perkambangannya adalah : (1) Pengembangan aspek kognitif (2) pengembangan aspek bahasa (3) Pengembangan aspek social emsional (4) Pengembangan aspek Fisik motoric (5) Pengembangan aspek Nilai agama dan moral dan (6) Pengembangan aspek Seni. Secara umum pada aktifitas bermain mewarna Damar Kurung ini akan memberikan pengaruh kepada hamper semua aspek perkembangan anak usia dini ini ${ }^{11}$. Terutam yang langsung berpengaruh adalah pada aspek pengembangan kognitif, Bahasa, social emosiaonal, fisik motoric dan Seni ${ }^{12}$.

\section{Mewarnai Damar kurung Sebagai media Pemahaman Protokol Kesehatan}

Gresik adalah sebuah wilayah Kabupaten yang berada di Provinsi Jawa Timur, berbatasan dengan Surabaya dan Selat Madura. Karena sebagian wilayah Kota Gresik adalah pesisir pantai

\footnotetext{
7 IDAI, "Panduan Klinis Tata Laksana COVID-19 Pada Anak."

${ }^{8}$ M Latif, M; Zukhairana; Zubaidah, R; Affandi, Orientasi Pendidikan Anak Usia Dini, 2013.

${ }^{9}$ Yeni Rachmawati, "Perkembangan Sosial Emosional Pada Anak Usia Taman Kanak-Kanak," Modul 1 PAUD, 2000, 1.1-1.43

${ }^{10}$ Nurmadiah Nurmadiah, "Strategi Pembelajaran Anak Usia Dini," Al-Afkar: Jurnal Keislaman \& Peradaban 3, no. 1 (2016): 1-28, https://doi.org/10.28944/afkar.v3i1.101.

${ }^{11}$ Carole Wade and Carole Tavris, PSIKOLOGI, PENERBIT ERL ANGGA, 2010, https://doi.org/10.1103/PhysRevD.87.092006.

12 Nuraeni Nuraeni, "Strategi Pembelajaran Untuk Anak Usia Dini," Prisma Sains : Jurnal Pengkajian Ilmu Dan Pembelajaran Matematika Dan IPA IKIP Mataram 2, no. 2 (2014): 143, https://doi.org/10.33394/j-ps.v2i2.1069.
}

4 Riyadlotus Sholichah - Pengasuhan Berbasis Neurosain dan Kecerdasan Emosi dalam Pengasuhan Anak Usia Dini 
dan ditambah letak geografisnya yang sangat strategis maka tidak heran jika banyak kapal-kapal pesiar maupun pedagang yang banyak berlabuh di Kabupaten Gresik. Pada abad ke-11, Gresik yang pada saat itu tidak memiliki nama, merupakan pusat perdagangan dan merupakan kota bandar yang banyak dikunjungi oleh bangsa-bangsa lain seperti Cina, Arab, dan dari Gujarat. Gresik juga merupakan pintu masuk agama Islam pertama di pulau Jawa yang ditandai dengan adanya makam-makam Islam kuno dari Syekh Maulana Malik Ibrahim dan Fatimah binti Maimun. Agama Islam masuk ke pulau Jawa tidak lepas dari para pedagang Arab yang berlabuh di Gresik. Cara mereka menyebarkan agama Islam adalah ketika mereka sedang berlabuh, para pedagang Arab ini melakukan penyiaran agama atau biasa disebut berdakwah kepada masyarakat Gresik.

Pada abad ke-14, barulah Gresik didirikan dan diberi nama oleh orang yang berasal dari etnis Tionghoa. Dan pada saat itu Gresik sudah menjadi salah satu pelabuhan utama dan kota dagang yang cukup penting. Selain merupakan tempat berlabuhnya kapal-kapal yang berasal dari timur tengah. Gresik juga merupakan tempat persinggahan kapal-kapal yang berasal dari Maluku menuju Sumatra dan daratan Asia ${ }^{13}$. Karena pada awal didirikannya kota Gresik oleh orang dari Tionghoa maka banyak sekali kebudayaan Cina yang masuk ke Gresik dan salah satunya adalah kebudayaan lampion. Damar kurung mengadaptasi lampion yang dipakai warga Tionghoa sebagai wujud kesempurnaan dan keberuntungan. Dulu, jika ada warga yang kesripahan (kesusahan karena di antara anggota keluarga ada yang meninggal dunia) maka lampion putih dipasang berpasangan di depan rumah yang melambangkan duka cita. Biasanya lampion berbentukbulat atau oval berwarna putih ini dibubuhi kaligrafi berisi penggalan syair Cina kuno. Sebaliknya, lampion bulat berwarna merah menjadi simbol keberuntungan dan kesempurnaan ${ }^{14}$. Seiring perkembangannya lampion diubah menjadi damar kurung yang sekarang menjadi ciri khas atau ikon yang ada di Gresik.

Masyarakat Gresik adalah masyarakat yang mayoritas penganut agama Islam. Dimana kegiatan-kegiatan keagamaan sangat kental dan mewarnai kondisi sosial masyarakat di sana. Seperti halnya kegiatan belajar membaca Al-Quran pada anak-anak kecil di Gresik, kegiatan sholat berjamaah, dan lain sebagainya. Bahkan kesenian di daerah Gresik sangat kental dengan nuansa islami, seperti halnya kesenian Hadra. Sangat kentalnya pengaruh islam dalam kehidupan masyarakat di Gresik. kegiatan-kegiatan tersebut di rekam oleh Masmundari dan kemudian di tuangkan dalam bentuk gambar pada Damar Kurung ${ }^{15}$.

Kegiatan mewarnai Media Damar kurung dipilih sebagai media untuk meningkatkan pemahaman anak dalam hal penerapan protokol kesehatan dengan tujuan agar anak lebih memahami langkah-langkah protokol kesehatan pada masa pandemi COVID-19 secara konkrit karena secara jelas telah tergambar tahapannya di dalam aktifitas mewarnai damar kurung. Pada aktifitas mewarnai ini didukung edukasi berupa Gambar atau video tentang sosialisasi protocol kesehatan anak dalam mememahami bahaya serta pencegahan penularan virus corona. Setelah itu, ajak anak untuk mempraktikkan berbagai protokol kesehatan itu melalui yang telah dibuat.

\footnotetext{
${ }^{13}$ Muhammad Nur et al., "Perancangan Buku Damar Kurung Gresik Dengan Teknik Vector Sebagai Upaya Mengenalkan Kebudayaan Kabupaten Gresik INSTITUT BISNIS DAN INFORMATIKA STIKOM SURABAYA" 5, no. 2 (2016).

14 Nur et al.

15 Ayudhea Dwi Meitasari, "Damar Kurung Pada Masa Pemerintahan Bupati Sambari Halim Tahun 2010-2015," Avatara 5, no. 3 (2017).
} 
Metode yang digunakan dalam penelitian ini adalah kualitatif deskriptif. Penelitian dilaksanakan di Wilayah Sidokumpul Kecamatan Gresik Kabupaten Gresik dimana termasuk desa dengan status wilayah covid "merah". Adapun kegiatan memberikan edukasi mengenai pentingnya protokol Kesehatan pada Anak - anak dengan menggunakan media Damar Kurung melalui tahapan- tahapan sebagai berikut :

a Persiapan aktifitas penelitian di WilayahSidokumpul dimulai dengan meminta izin kepada Lurah setempat untuk melaksanakan kegiatan di wilayah tersebut dengan sasaran anak-anak untuk pengenalan pentingnya protokol kesehatan melalu daring yang dilaksanakan pada tanggal 10 Agustus 2020 - 10 September 2020. Berikutnya kami meminta izin kepada beberapa orangtua yang memiliki anak usia TK - SD untuk mengikuti kegiatan penelitian yang sudah di rencanakan dengan melalui observasi terlebih dahulu.

b. Pelaksanaan disesuaikan dengan kondisi Kabupaten Gresik masih dalam Zona Merah maka secara umum Kegiatan ini dilaksanakan melalui daring dengan banyak memebetikan file-file aturan, kesepakatan dan tutorial serta materi melalui mengirim Video Edukasi pada anak - anak melalui WA orang tua. Selanjutnya orang tua dan anak mendapatkan sepaket media praktik mewarnai Damarkurung dengan beberapa kit pelengkapnya, yang dikerjakan dirumah Bersama orang tua melalui panduan file yang telah dikirimkan melalui wa. Adapun beberapa tahapan dan materi yang disampaikan antara lain :

1. Perkenalan

2. Memberikan cerita tentang Sejarah dan pengertian Damar Kurung sebagai karya seni khas Kabupaten Gresik.

3. Pentingnya penerapan protokol kesehatan selama masa pandemi.

4. Tujuh langkah cara mencuci tangan.

5. Membagikan kerangka dan gambar untuk membuat Damar Kurung dan masker pada anak - anak.

6. Tutorial mewarnai dan membuat Damar Kurung dengan tema Protokol Kesehatan.

Dari hasil penelitian ini dapat dipaparkan beberapa hasil antara lain, kegiatan

menggambar dan mewarnai damar kurung dengan gambar dinilai sangat membantu anak dalam membiasakan diri dalam mematuhi protokol kesehatan. Serta menjadi hiburan bagi anak - anak untuk mengisi kegiatan sehari - hari agar tidak jenuh dalam kegiatan pembelajaran daring dari sekolah. Namun ada pula anak yang kurang merespon baik kegiatan ini dan terlambat mengikuti daring dikarenakan orang tua yang sedang bekerja dan ada pula beberapa yang memprioritaskan pekerjaan sekolah. Sehingga pembuatan Damar Kurung dengan tema Protokol kesehatan tidak bisa dilaksanakan dengan serentak. Dari observasi yang dilakukan secara mendalam melaui wawancara online dan observasi offline kepada orang tua dan anak didapatkan beberapa hasil observasi sebagai berikut :

a. Anak mengetahui tentang pentingnya mematuhi protokol kesehatan dimasa pandemi Covid -19 .

b. Anak mengetahui langkah - langkah dalam pencegahan Covid 19 yang harus dilakukan sehari - hari.

c. Anak mengenal lebih dekat karya seni Damar Kurung yang merupakan karya seni khas Kabupaten Gresik.

d. Anak dapat membuat sendiri dan berkreasi membuat Damar kurung dengan tema Protokol Kesehatan. 


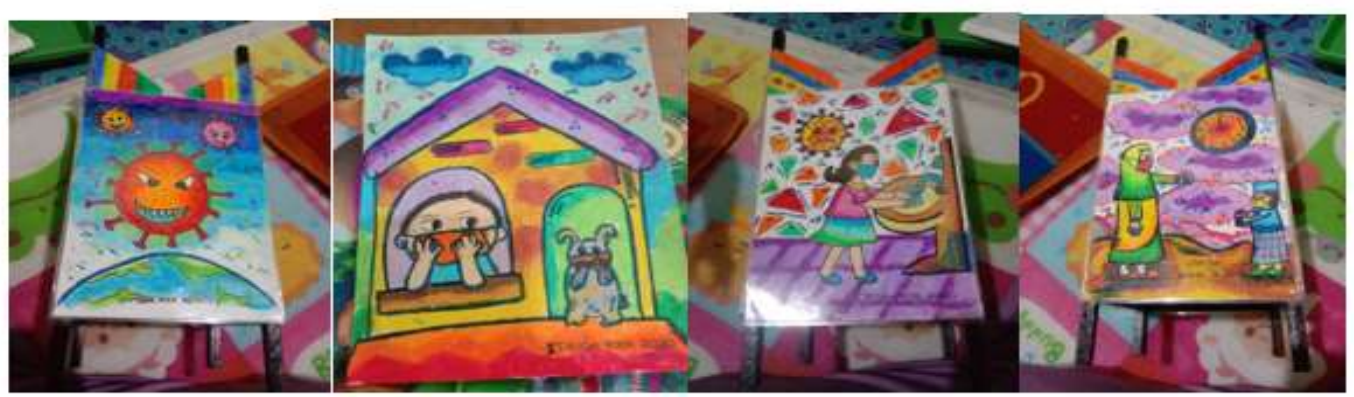

Gambar 1. Media Damar Kurung bergambar Protokol Kesehatan

(Foto koleksi pribadi)

\section{Kesimpulan}

Melalui penelitian ini dapat disimpulkan bahwa kegiatan mewarnai menggunakan media Damar Kurung cukup efektif dalam sosialisasi protokol kesehatan pada anak. Selain dapat memberikan wawasan tentang protokol kesehatan, anak - anak juga dikenalkan dengan karya seni lokal di Kabupaten Gresik yang berupa damar kurung. Kegiatan ini dinilai dapat memberi pengalaman baru serta memberi pilihan aktifitas rekreatif pada anak- anak yang dirasa cukup jenuh dengan kegiatan daring dari sekolah hal ini dapat dilihat dari respon anak - anak dan orang tua yang cukup antusias dalam pembuatan Damar Kurung dengan tema Protokol Kesehatan. Senada dengan respon positif yang disampaikan oleh beberapa orang tua anak bahwa Kegiatan ini merupakan kegiatan yang dapat memberikan pemahaman tentang protocol Kesehatan pada anak - anak ditengah pembelajaran online yang saat ini sedang berlangsung.

\section{Daftar Pustaka}

Dewi, Wahyu Aji Fatma. "Dampak COVID-19 Terhadap Implementasi Pembelajaran Daring Di

Sekolah Dasar." Edukatif: Jurnal Ilmu Pendidikan 2, no. 1 (2020): 55-61.

https://doi.org/10.31004/edukatif.v2i1.89.

Dwi Meitasari, Ayudhea. "Damar Kurung Pada Masa Pemerintahan Bupati Sambari Halim Tahun

2010-2015." Avatara 5, no. 3 (2017).

IDAI. "Panduan Klinis Tata Laksana COVID-19 Pada Anak." Indonesian Pediatric Society, 2020, 33. KPPA. "Pedoman Umum Perlindungan Anak Penanganan COVID-19," 2020.

Latif, M; Zukhairana; Zubaidah, R; Affandi, M. Orientasi Pendidikan Anak Usia Dini, 2013.

Nugroho, Isfauzi Hadi, and Dema Yulianto. "Penerapan Disiplin Protokol Kesehatan Di Era

KENORMALAN BARU PADA DUNIA PAUD.” Jurnal Al-Hikmah 8, no. 1 (2020): 150-56.

Nur, Muhammad, Fithriyadi Darwin, Yuwono Riyanto, and Wahyu Hidayat. "Perancangan Buku

Damar Kurung Gresik Dengan Teknik Vector Sebagai Upaya Mengenalkan Kebudayaan

Kabupaten Gresik INSTITUT BISNIS DAN INFORMATIKA STIKOM SURABAYA” 5, no. 2 (2016).

Nuraeni, Nuraeni. "Strategi Pembelajaran Untuk Anak Usia Dini.” Prisma Sains : Jurnal Pengkajian 
Ilmu Dan Pembelajaran Matematika Dan IPA IKIP Mataram 2, no. 2 (2014): 143.

https://doi.org/10.33394/j-ps.v2i2.1069.

Nurmadiah, Nurmadiah. "Strategi Pembelajaran Anak Usia Dini.” Al-Afkar : Jurnal Keislaman \& Peradaban 3, no. 1 (2016): 1-28. https://doi.org/10.28944/afkar.v3i1.101.

Rachmawati, Yeni. "Perkembangan Sosial Emosional Pada Anak Usia Taman Kanak-Kanak.” Modul 1 PAUD, 2000, 1.1-1.43.

Wade, Carole, and Carole Tavris. PSIKOLOGI. PENERBIT ERLANGGA, 2010.

https://doi.org/10.1103/PhysRevD.87.092006.

Wahyu, Rizky Sandika. "Damar Kurung (Makna Lukisan Damar Kurung Sebagai Kesenian Masyarakat Gresik)" 2, no. 1 (2013): 114-23. 